\title{
Performance of Tharparkar calves following a suckling or non-suckling rearing system
}

\author{
Vipin Kumar Upadhyay, A. K. S. Tomar, B. H. M. Patel, S. Sahu, P. K. Bharti and D. M. Golher \\ Livestock Production \& Management Section, Indian Veterinary Research Institute, Izatnagar, Uttar Pradesh, India. \\ Corresponding author: S. Sahu, e-mail: subhasishsahu72@gmail.com, \\ VKU: vipinupadhyay4@gmail.com, AKST: drakstomar@gmail.com, BHMP: mpatellpm@gmail.com, \\ PKB: pkish.1002@gmail.com, DMG: golherdurgesh17@gmail.com \\ Received: 17-07-2014, Revised: 26-10-2014, Accepted: 03-11-2014, Published online: 11-12-2014
}

doi: 10.14202/vetworld.2014.1071-1074. How to cite this article: Upadhyay VK, Tomar AK, Patel BHM, Sahu S, Bharti PK, Golher DM (2014) Performance of Tharparkar calves following a suckling or non-suckling rearing system, Veterinary World, 7(12): 1071-1074.

\begin{abstract}
Aim: The aim was to find out the influence of suckling and non-suckling system of rearing on growth performance of indigenous Tharparkar calves.

Materials and Methods: A total of 14 Tharparkar calves was randomly divided into two groups. The Group 1 (G-1) was suckling group, in which calves were allowed to suckle from the same dam twice a day before/after milking from birth to 90 days of age, while in Group 2 ( $\mathrm{G}$ 2), calves were weaned (non-suckling) immediately after birth (1) day weaning). The non-suckling calves were fed with colostrum within few hours after birth and twice daily for 3 days at the rate of $10 \%$ of live body weight (LBW) and later, kept under pail feeding till 71 days of age along with calf starter and green fodder as per the Indian Veterinary Research Institute protocol. The experimental trial was continued for 90 days of age of calf from its birth. Observations regarding various growth performances were made following standard procedures and the data obtained were statistically analyzed by SPSS program version 17.

Results: The effect of rearing system was found to be significantly ( $\mathrm{p} \leq 0.05)$ higher for $\mathrm{G} 1$ calves on 15 days LBW whereas it was highly significant ( $\leq 0.01$ ) on LBW's at subsequent readings as compared to $\mathrm{G} 2$ calves. For average daily gain (ADG) (g/day), $\mathrm{G} 1$ calves showed highly significant $(\mathrm{p} \leq 0.01)$ value than $\mathrm{G} 2$ calves during $0-30$ days $(447.62 \pm 58.13$ in $\mathrm{G} 1$ vs.

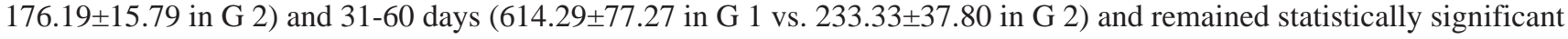
$(\mathrm{p} \leq 0.05)$ between 61 and 90 days. On different body measurements, effect of system of rearing was non-significant up to 15 days. From 30 days onwards, higher significant values for $\mathrm{G} 1$ calves were observed for heart girth and body length whereas for body height significant results were obtained from 45 days onward. This superiority in all growth parameters expressed by suckling system calves might be due to longer duration of milk feeding and more intake of milk as compared to that of non-sucking group.
\end{abstract}

Conclusion: Therefore present study was concluded that the calves reared under suckling system attained higher LBW, ADG in body weight and body measurements than the non-suckling group of Tharparkar calves.

Keywords: body measurements, growth, suckling, Tharparkar calves, weaning.

\section{I ntroduction}

The successful calf rearing is the key of any dairy farm enterprise because these young calves will be the future replacement stock of dairy farm. Therefore, calf management should be scientific, proper, and appropriate.

Calf rearing is done either by natural suckling or artificial rearing, i.e., weaning. Rearing after birth may have a significant impact on subsequent performance [1-3] and behavior of animals. Proper rearing conditions of a healthy and viable calf in this period are another prerequisite for making the best use of its genetic potential for dairy cows [4-6]. This is more beneficial in terms of scientific feeding of required quantity of milk and calf-starter to record actual milk production of dam under more hygienic and sanitary conditions, even restricted suckling may be a simple

Copyright: The authors. This article is an open access article licensed under the terms of the Creative Commons Attributin License (http:// creative commons.org/licenses/by/2.0) which permits unrestricted use, distribution and reproduction in any medium, provided the work is properly cited. and viable alternative for dairy farmers interested in obtaining heavier male and female calves without substantially affecting the management of the herd [7]. In general, early weaning (non-suckling) is a common practice followed mostly in exotic and crossbred dairy animals, but the literature on indigenous animals are scanty.

Therefore, the present study was envisaged to know the effect of rearing system on performance of Tharparkar calves under organized farming condition.

\section{Materials and Methods}

\section{Ethical approval}

The experiment followed the guidelines of Institutional Animal Ethics Committee.

\section{Experimental site}

The relevant data were generated and recorded based on trial planned on fourteen Tharparkar calves, based on availability, reared at Cattle and Buffalo Farm, Livestock Production Management Section, Indian Veterinary Research Institute (IVRI), Izatnagar, 
Bareilly, Uttar Pradesh (India). The IVRI, Izatnagar is situated in India at $28.22^{\circ} \mathrm{N}$ latitude, $79.22^{\circ} \mathrm{E}$ longitude and an altitude of 568' above mean sea level. The climatic condition is extremely hot during summers (May-June) and very cold during winters (DecemberFebruary) with average annual rainfall ranges from 90 to $120 \mathrm{~cm}$. The institute has 165 ha of well-irrigated fodder cultivation land to ensure round the year supply of green fodder to these animals.

\section{Animals}

A total of 14 calves born in winter season (October-December) was divided randomly and alternatively into two groups of seven calves in each viz. suckling Group 1 (G 1) and non-suckling Group 2 (G 2), respectively, depending on their body weight (BW) and irrespective of their sex and the experiment was continued up to the end of February. The G 1 calves were allowed to suckle from the same dam twice a day before/after milking from birth to 90 days of age, while in $\mathrm{G} 2$, calves were weaned immediately after birth (1st day weaning) and termed as non-suckling group. The experimental trial was continued for 90 days of age of calf from its birth. Each calf in G 1 was fed with colostrum of its own dam within few hours after birth and twice daily for first 3 days of age and later that was allowed to suckle its dam twice daily before/after milking. The non-suckling calves (G 2) were fed as per standard protocol followed at IVRI and presented in Table-1a. The amount of milk was given to $G 2$ calves with the help of milk pail (wide mouth bucket) as per their age and BW and it was adjusted fortnightly. Along with milk, calves were provided ad-lib. Calf starter (Table-1b.) and succulent green fodder as early as possible. The calves

Table-1a: Feeding schedule of non-suckling (weaned) calves.

\begin{tabular}{|c|c|c|c|c|}
\hline Age of calf & Colostrum & $\begin{array}{l}\text { Whole } \\
\text { milk }\end{array}$ & Concentrate & $\begin{array}{l}\text { Green } \\
\text { fodder }\end{array}$ \\
\hline $0-3$ days & $1 / 10^{\text {th }}$ of $B W$ & Nil & $\mathrm{Nil}$ & Nil \\
\hline 4-56 days & Nil & $\begin{array}{l}1 / 10^{\text {th }} \\
\text { of } \mathrm{BW}\end{array}$ & \multirow{3}{*}{\multicolumn{2}{|c|}{$\begin{array}{l}\text { Ad lib. from } 15^{\text {th }} \text { day } \\
\text { onwards }\end{array}$}} \\
\hline 57-63 days & Nil & $\begin{array}{l}1 / 20^{\text {th }} \\
\text { of } \mathrm{BW}\end{array}$ & & \\
\hline 64-71 days & $\mathrm{Nil}$ & $\begin{array}{l}1 / 40^{\text {th }} \\
\text { of } \mathrm{BW}\end{array}$ & & \\
\hline
\end{tabular}

BW: Body weight

Table-1b: Composition of calf starter.

\begin{tabular}{lc}
\hline Ingredients & Level (\%) \\
\hline Barley & 50 \\
Groundnut cake & 30 \\
Wheat bran & 10 \\
Fish meal & 7 \\
Mineral mixture & 2 \\
Common salt & 1 \\
Calculated value & \\
CP & 22 \\
TDN & 71 \\
\hline
\end{tabular}

TDN $=$ Total digestible nutrients, $\mathrm{CP}=$ Crude protein were kept individually in well-ventilated, clean and dry pacca pens during milk feeding and at night hour. Rest of the part they were kept in the open paddock and were free access to calf starter along with green succulent forage (berseem, maize, and oat).

The parameters recorded and analyzed were daily milk intake, live BW (LBW), body measurements and average daily gain (ADG) in weight. BW was recorded immediately before and after suckling on digital weighing balance kept at calf unit to calculate the total milk consumed by the G 1 calf. BW and body measurements of calves were recorded simultaneously at every 15 days interval from birth to 90 days of age before offering them feed and water. Body length (BL) was measured from the point of shoulder to point of pin bone. Body height $(\mathrm{BH})$ at withers was recorded from ground level to the highest point of shoulder and heart girth (HG) was measured behind the point of elbow. These measurements were recorded in centimeter $(\mathrm{cm})$ using standard measuring tape by individually measuring each of the experimental calves at the time of weighing.

\section{Statistical analysis}

The data were analyzed using statistical measures with one-way ANOVA analysis using SPSS pro-gram version 17 (IBM corporation, USA).

\section{Result and Discussion}

Fortnightly BW and body measurements were presented in Table-2. At the beginning of the experiment BW was similar in both treatments, however, differences $(\mathrm{p}<0.05)$ in BW were observed from 15 day onward. At the end of the experiment G 1 showed significantly more BW than $G 2$ (G 1: $75.9 \pm 6.42 \mathrm{~kg}, \mathrm{G} 2: 47.00 \pm 3.30 \mathrm{~kg}$ of BW). Similar to the above trend on BW, G 1 calves showed $(\mathrm{p} \leq 0.01)$ higher ADG (g/day) than G 2 calves during 0-60 d. Cumulative ADG from 0 to 60 days $(530.95 \pm 67.40 \mathrm{~kg}$ vs. $204.76 \pm 24.86 \mathrm{~kg})$ and $0-90 \mathrm{~d}(598.41 \pm 65.03 \mathrm{~kg}$ vs. $285.71 \pm 37.70 \mathrm{~kg}$ ) was also highly significant for G 1 calves than G 2 calves. Though the non-suckling calves expressed gradual improvement in their LBW's and ADG during the experimental period but it was significantly lower than their suckling counterparts (Table-2). Similar to our findings, [8] reported in Murrah buffalo calves that the LBW's of early weaned calves were inferior to those of suckled calves. Similarly, [9] in buffalo calves reported that LBW's of early weaned calves were inferior to those of late weaned calves. In a study of Holstein Friesian calves, the production parameter and weight gains were higher in suckling calves that were allowed to suckle from birth to 6 weeks of age than artificially reared calves [10]. However, present results were not in agreement with the observations made by Myers et al. [11] and Wertz et al. [12], who reported that early-weaned calves had more gains than traditionally 


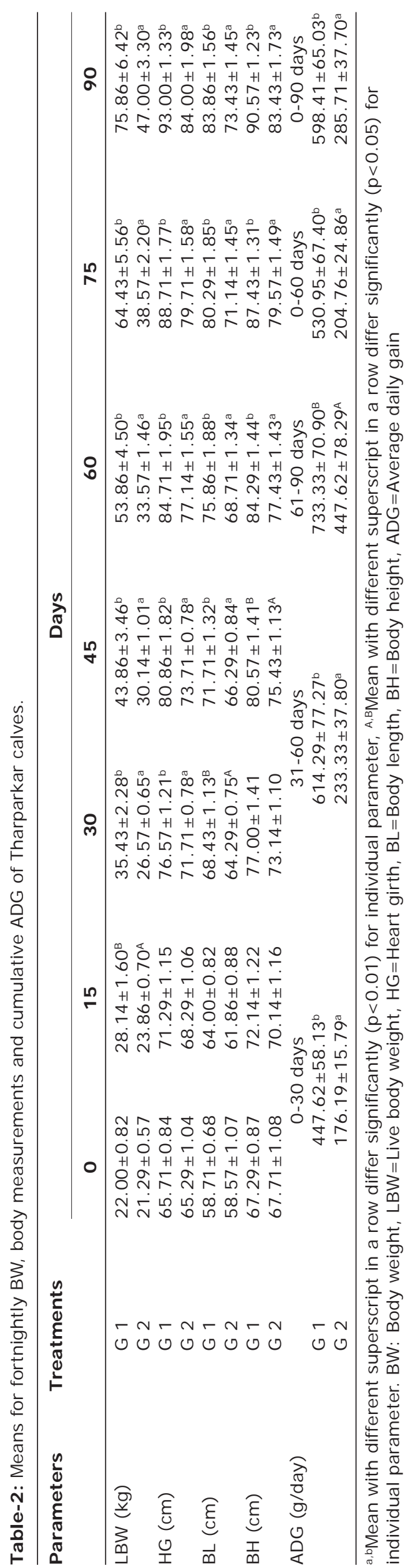

weaned calves. The superior LBW's and ADG expressed by G 1 calves might be due to longer duration (90 days) of milk feeding and more intake of milk in $\mathrm{G} 1$ (258.70 $\pm 6.95 \mathrm{~kg}$ in 90 days) as compared to $\mathrm{G} 2(163.90 \pm 4.44 \mathrm{~kg}$ in 71 days) where the calves were fed milk only for 71 days that too on pre-decided recommended milk feeding schedule (Table-3.) Our results for more milk intake by $\mathrm{G} 1$ calves was in accordance with [13] who reported that unweaned calves can drink more milk than traditionally provided to them without any negative effects on their health. Significantly, more growth in G 1 may also be due to daily dam-calf social interaction at the time of milking which might have influenced the growth of calves positively [14] and may be due to native maternal milk obtained to offspring which might have impacted offspring behavior and resulted in subsequent health and development [15].

Effect of different system of rearing was non-significant on HG up to 15 days, whereas from 30 to 90 days, differences $(\mathrm{p} \leq 0.01)$ were obtained for G 1 calves than G 2 calves. Similarly, [8] reported that in Murrah buffalo calves, the suckling calves showed a greater increase in HG as compared to weaned calves. On BL, both groups were comparable up to 15 days, but on 30th day it was significantly higher for $\mathrm{G} 1(68.43 \pm 1.13 \mathrm{~cm})$ as compared to $\mathrm{G} 2(64.29 \pm 0.75 \mathrm{~cm})$ whereas on subsequent measurements, $G 1$ calves showed differences $(\mathrm{p} \leq 0.01)$ as compared to G 2 (Table-2). BH was found to be comparable for both the groups up to 30 days, but at 45 days it was higher $(p \leq 0.05)$ for $\mathrm{G} 1(80.57 \pm 1.41 \mathrm{~cm})$ as compared to $\mathrm{G} 2(75.43 \pm 1.13 \mathrm{~cm})$ and on subsequent recordings a higher significant difference were observed. These findings were corroborated with [8] and [10] that the suckling calves had higher height at wither as compared to weaned calves. Significantly higher body measurements in G 1 is an alternate measures of higher growth rate which is already reflected on the BW and ADG which might be due to longer duration of milk feeding, more intake of milk [13] and native maternal milk obtained to offspring [15] or might be due to daily dam-calf social interaction [14] resulted in positive growth.

\section{Conclusion}

The present study was concluded that the calves reared with suckling system attain higher LBW, ADG in weight and higher body measurements than the weaning (non-suckling) system of rearing which provided the baseline information on weaning system of rearing of Indigenous native breed of cattle.

\section{Authors' Contributions}

VKU did the physical experiment and DMG assisted in the work. AKT designed the work, and BHMP guided the experiment. SS did the statistical analysis and PKB revised the manuscript. All authors finally approved the manuscript. 
Table-3: Least squares' means for overall monthly and per day (of different durations) MC up to 90 days.

\begin{tabular}{|c|c|c|c|c|c|c|c|c|}
\hline \multirow[t]{2}{*}{ Treatments } & \multicolumn{4}{|c|}{ MC ( $\mathrm{kg})$ during } & \multicolumn{4}{|c|}{ Per day MC ( $k g)$ during } \\
\hline & $1^{\text {st }}$ month & $2^{\text {nd }}$ month & $3^{\text {rd }}$ month & $\begin{array}{c}\text { 0-90 day } \\
(\mathrm{kg})\end{array}$ & $1^{\text {st }}$ month & $2^{\text {nd }}$ month & $3^{\text {rd }}$ month & $\begin{array}{c}\text { 0-90 day } \\
(\mathbf{k g})\end{array}$ \\
\hline G 1 & $87.29 \pm 2.73^{b}$ & $89.27 \pm 2.33^{B}$ & $82.14 \pm 3.30^{b}$ & $258.70 \pm 6.95^{b}$ & $2.91 \pm 0.09^{b}$ & $2.98 \pm 0.08^{B}$ & $2.74 \pm 0.11^{b}$ & $2.87 \pm 0.08^{b}$ \\
\hline G 2 & $69.31 \pm 2.17^{a}$ & $81.10 \pm 2.40^{\mathrm{A}}$ & $13.49 \pm 0.51^{\mathrm{a}}$ & $163.90 \pm 4.44^{\mathrm{a}}$ & $2.31 \pm 0.07^{a}$ & $2.70 \pm 0.08^{\mathrm{A}}$ & $1.23 \pm 0.05^{a}$ & $2.31 \pm 0.06^{\mathrm{a}}$ \\
\hline
\end{tabular}

a,bMean with different superscript in a row differ significantly $(p<0.01)$, A,BMean with different superscript in a row differ significantly $(p<0.05), M C=$ Milk consumption

\section{Acknowledgments}

The authors are thankful to the Director and Joint Director (Academic) of IVRI, Izatnagar for providing necessary funds and facilities to carry out research.

\section{Competing I nterests} interests

The authors declare that they have no competing

\section{References}

1. Terré, M., Tejero, C. and Bach, A. (2009) Long-term effects on heifer performance of an enhanced growth feeding programme applied during the pre-weaning period. J. Dairy Res., 76(3): 331-339.

2. Moallem, U., Werner, D., Lehrer, H., Kachut, M., Livshitz, L., Yakoby, S. and Shamay, A. (2010) Long-term effects of feeding ad-libitum whole milk prior to weaning and prepubertal protein supplementation on skeletal growth rate and first-lactation milk production. J. Dairy Sci., 93(6): 2639-2650.

3. Soberon, F., Raffrenato, E., Everett, R.W. and Van Amburgh, M.E. (2012) Early life milk replacer intake and effects on long term productivity of dairy calves. J. Dairy Sci., 95(2): 783-793.

4. Frelich, J., Šlachta, M., Szarek, J., Węglarz, A. and Zapletal, P. (2008) Seasonality in milk performance and reproduction of dairy cows in low-input farms depending on feeding system. J. Anim. Feed Sci., 18: 197-208.

5. Řehak, D., Rajmon, R., Kubešova, M., Štipkova, M., Volek, J. and Jilek, F. (2009) Relationships between milk urea and production and fertility traits in Holstein dairy herds in the Czech republic. Czech J. Anim. Sci., 54: 193-200.

6. Shamay, A., Werner, D., Moallem, U., Barash, H. and Bruckental, I. (2005) Effect of nursing management and skeletal size at weaning on puberty, skeletal growth rate, and milk production during first lactation of dairy heifers. $J$. Dairy Sci., 88(4): 1460-1469.
7. Mendoza, A., Cavestany, D., Roig, G., Ariztia, J., Pereira, C., La Manna, A., Contreras, D.A. and Galina, C.S. (2010) Effect of restricted suckling on milk yield, composition and flow, udder health, and postpartum anoestrus in grazing Holstein cows. Livest. Sci., 127: 60-66.

8. Kantharaja, K.J. (2011) Comparative Study of Weaned Murrah buffalo Calves at Cattle and Buffalo Farm of IVRI. Thesis, M.V.Sc. Deemed University, IVRI, Izatnagar, India.

9. Khoury R.H. and Pickering, F.S. (1969) Nutrition of the milk fed calf, I. Performance of calves fed on different levels of whole milk relative to body weight. N. Z. J. Agric. Res., 11: 227-236.

10. Bar-Peled, U., Robinzon, B., Maltz, E., Tagari, H., Folman, Y., Bruckental, I., Voet H., Gacitua, H. and Lehrer, A.R. (1997) Increased weight gain and effects on production parameters of Holstein heifer calves that were allowed to suckle from birth to six weeks of age. J. Dairy Sci., 80: 2523-2528.

11. Myers, S.E., Faulkner, D.B., Ireland, F.A., Berger, L.L. and Parrett, D.F. (1999) Production systems comparing early weaning to normal weaning with or without creep feeding for beef steers. J. Anim. Sci., 77(2): 300-310.

12. Wertz, A.E., Berger, L.L., Walker, P.M., Faulkner, D.B., McKeith, F.K. and Rodriguez-Zas, S.L. (2002) Early weaning and post weaning nutritional management affect feedlot performance, carcass merit, and the relationship of $12^{\text {th }}$ rib fat, marbling score, and feed efficiency among Angus and Wagyu heifers. J. Anim. Sci., 80: 28-37.

13. Borderas, T.F., De Passille, A.M.B. and Rushen, J. (2009) Feeding behavior of calves fed small or large amounts of milk. J. Dairy Sci., 92(6): 2843-2852.

14. Kisac, P., Broucek, J.J., Uhrincat, M. and Hanus, A. (2011) Effect of weaning calves from mother at different ages on their growth and milk yield of mothers. Czech J. Anim. Sci., 56(6): 261-268.

15. Hinde, K. and Capitanio, J.P. (2010) Lactational programming? Mother's milk energy predicts infant behavior and temperament in rhesus macaques (Macacamulatta). Am. $J$. Primatol., 72(6): 522-529. 